ДЕРЖАВНО-ПРИВАТНЕ ПАРТНЕРСТВО ЯК ФІНАНСОВИЙ МЕХАНІЗМ ЗАБЕЗПЕЧЕННЯ ІННОВАЦІЙНОГО РОЗВИТКУ НАЦІОНАЛЬНОЇ ЕКОНОМІКИ

\title{
PUBLIC-PRIVATE PARTNERSHIPS AS FINANCIAL MECHANISM OF PROVIDING INNOVATIVE DEVELOPMENT OF THE NATIONAL ECONOMY
}

Удк 334.012

https://doi.org/10.32843/infrastruct33-18

\section{Філіпова Н.В.}

к.е.н., доцент,

доцент кафедри публічного управління

та менеджменту організацій

Чернігівський національний

технологічний університет

Старченко Г.В.

к.т.н., доцент,

докторант кафедри публічного

управління та менеджменту організацій

Чернігівський національний

технологічний університет

\begin{abstract}
у статті розглянуто організаційно-економічний механізм активізації інноваційної діяльності за рахунок державно-приватного партнерства. Головну увагу приділено максимізації участі бізнесу в інноваційних процесах України. Проаналізовано сфеери застосування державно-приватного партнерства різними країнами. Виявлено, що державно-приватне партнерство в інноваційно-інвестиційній сфері розглядається як нові технології розвитку економіки і $є$ вагомим фокатором інноваційно-інвестиційної безпеки національної економіки. Виділено основні принципи, на які спирається державно-приватне партнерство в інноваційній сфрері. Зазначено, що основною перевагою ДПП $є$ оптимальний розподіл повноважень щодо контролю над спільною діяльністю 3 надання послуг населенню. Також у статmі проведено порівняльну характеристику форм ДПП, досліджено механізми співпраці державних структур та приватного сектору. Проведений аналіз дав змогу розглянути структуру організаційно-економічного механізму регулювання ДПП, цілями якого $\epsilon$ фрормування ефрективних джерел ресурсів інноваційних проектів, створення умов для успішної реалізації стратегічних планів інноваційного розвитку національної економіки, формування механізмів забезпечення стабільності та підвищення конкурентоспроможності економіки Україні.

Ключові слова: державно-приватне партнерство, інновація, розви-ток, інноваційний розвиток, національна економіка.
\end{abstract}

В статье рассмотрен организационно-экономический механизм активизации инно- вационной деятельности за счет государственно-частного партнерства. Главное внимание уделено максимизации участия бизнеса в инновационных процессах Украины. Проанализированы сфреры применения государственно-частного партнерства в разных странах. Выявлено, что государственно-частное партнерство в инновационно-инвестиционной сфрере рассматривается как новые технологии развития экономики и является весомым фрактором инновационно-инвестиционной безопасности национальной экономики. Выделены основные принципы, на которые опирается государственно-частное партнерство в инновационной сорере. Отмечено, что основным преимуществом ГЧП является оптимальное распределение полномочий относительно контроля над совместной деятельностью по оказанию услуг населению. Также в статье проведена сравнительная характеристика форм ГЧП, исследованы механизмы сотрудничества государственных структур и частного сектора. Проведенный анализ позволил рассмотреть структуру организационно-экономического механизма регулирования ГЧП, целями которого является формирование эсрфрективных источников ресурсов инновационных проектов, создание условий для успешной реализации стра-тегических планов инновационного развития национальной экономики, формирование механизмов обеспечения стабильности и повышения конкурентоспособности экономики Украины. Ключевые слова: государственно-частное партнерство, инновации, развитие, инновационное развитие, национальная экономика.

The article deals with the organizational and economic mechanism of acti-vation of innovation activity at the expense of public-private partnership. The main attention is paid to maximizing business participation in innovative processes in Ukraine. There were analyzed areas of application of public-private partnership in different countries (USA, Spain, Australia, Nederland, Ireland, Greece, Canada, Great Britain). It was revealed that public-private partnership in the innovation-investment sphere is considered as new technologies of economic development and is a significant factor of innovation and investment security of the national economy. The main principles of public-private partners in innovation are highlighted (1) budget financing should act as a catalyst for innovation processes; 2) co-financing state projects while maintaining project management in the hands of business or specialized intermediary organizations; 3) implementation of the functions of support of the state of innovative companies through business intermediaries; 4) the use of different approaches of the state to the activation of innovative activities - both at the expense of administrative motivation of existing innovative enterprises, and through the creation of innovative business units; 5) the development of innovative clusters, within which an efficient exchange of best practices between small and mediumsized businesses is possible, in particular with the participation of state structures; 6) development of a system of informal interactions between innovators; 7) improvement of the regulatory framework. It is noted that the main advantage of PPP is the optimal allocation of powers to control the joint activities of providing services to the population. Also, in the article have com-parative description of PPP forms, mechanisms of cooperation between state structures and the private sector are explored. The analysis allowed to consider the structure of the organizational and economic mechanism of regulation of PPP-tion objectives which is to develop efficient sources of innovation resources, creating conditions for successful implementation of the strategic plans of innovative development of national economy, the formation mechanisms of stability and competitiveness of the economy of Ukraine.

Key words: project, innovation, development, project approach, innovative development, mechanisms of innovative development, public-private partnership.

Постановка проблеми. Соціально-економічний розвиток країни залежить від проведення послідовної інноваційної політики та ефективного впровадження інноваційної моделі на всіх рівнях державного управління. Інноваційний розвиток національної економіки $є$ важливим чинником підвищення її конкурентоспроможності.
Високі і стабільні темпи економічного зростання економіки мають до-сягатися переважно за рахунок інноваційних фракторів. Недостатня ефректив-ність інноваційних процесів розвитку економіки України супроводжується невирішеністю проблеми щодо узгодження механізмів поєднання ринкових чинників з державними методами регу- 
лювання інноваційної діяльності, фрорм участі держави і бізнесу у фрінансовому і інвестиційному забезпеченні інноваційної діяльності. Зростання інвестицій, яке відбувається в Україні, не сприяє збільшенню інновацій. У вітчизняній економіці менше 10\% від зага-льного обсягу інвестицій спрямовується на інновації, у той час, коли в розвинутих країнах світу інноваційне інвестування тримається на рівні 50-60\%. Основними причинами несприйнятливості господарюючих суб'єктів до інновацій є суттєві ресурсні обмеження, зокрема: відсутність достатніх власних коштів у підприємств; відносно дорогі кредити, високі ризики, які перешкоджають отриманню кредитів [1].

У розвинених країнах державне регулювання інноваційної діяльності $€$ економічно зумовленим і необхідним, оскільки переслідує мету створення найбільш сприятливих умов для інноваційного процесу, зокрема забезпечення позитивної динаміки економічного зростання, яка пов'язана 3 пошуком інвестиційних ресурсів і залученням усіх можливих фрінансових джерел, необхідних для фрінансування інноваційно-інвестиційних процесів, а також оптимізацією грошово-кредитних механізмів, якими вони регулюються. Проблема активізації діяльності держави у залученні фрінансово-кредитних інститутів у процес інвестування інноваційного розвитку країни вимагає комплексного дослідження умов, які впливають на цей процес, і безпосередньо усіх суб'єктів фрінансового ринку, які можуть бути у ньому задіяні [2].

Проблемна ситуація, що склалася в Україні у сорері фрінансового забез-печення інноваційного розвитку, ефективної реалізації інноваційної моделі, її здатності забезпечити довгострокове економічне зростання, вказує на необхідність використання потенціалу секторів державних і приватних фрінансів через їх взаємодію.

Аналіз останніх досліджень і публікацій. Питання в галузі теорії і практики державно приватного-партнерства та інноваційного розвитку національної економіки вивчалися та розвивалися в працях таких вітчизняних і зарубіжних вчених, як: В.М. Гєєць, А.С. Гальчинський, Ю.М. Бажал, М.С. Герасимчук, І.І. Лукінов, Б.А. Малицький, Я.А. Жаліло, О.В. Редькін, Д.М. Толкачов, Л.А. Сиволап, М. Фрідмен, Й. Шумпетер та інші.

Становище, яке спостерігається в інноваційній сорері України, засвідчує існування суттєвих системних перешкод формуванню інноваційної моделі розвитку України.

Незважаючи на велику кількість публікацій із питань державно приватного-партнерства та управління інноваційним розвитком, питання впливу організаційно-економічного механізму активізації інноваційної діяльності за рахунок державно-приватного партнерства висвітлені не досить повно.
Наявність невирішених завдань щодо функціонування економіки на засадах інноваційної моделі розвитку потребує впровадження ефрективного механізму фрінансового забезпечення, який би дозволив за наявності обмежених фрінансових ресурсів перетворити його зі статусу витратного у механізм, що забезпечує інноваційний розвиток національної економіки. Вирішення стратегічних завдань раціонального фрінансового забезпечення інноваційного розвитку національної економіки потребує раціонального використання наявних фрінансових ресурсів на рівні всіх суб'єктів господарювання що свідчить про необхідність дослідження цього питання.

Постановка завдання. Метою дослідження $€$ розроблення організаційно-економічного механізму активізації інноваційної діяльності за рахунок державно-приватного партнерства.

Виклад основного матеріалу дослідження. Причиною не досить ви-сокої інноваційної активності суб'єктів господарювання національної еконо-міки $€$ відсутність системного підходу до визначення пріоритетів державної політики в інноваційній сорері, державного замовлення на інноваційну продукцію, а також невизначеність принципів і механізму державно-приватного партнерства в інноваційній сорері [3].

Головна умова інноваційно розвитку національної економіки - максимізація участі бізнесу в інноваційних процесах країни. Співробітництво приватних структур у сорері законодавчих ініціатив і спільне з державою розроблення рішень - це запорука інноваційно-інвестиційної безпеки. Держава повинна виробити системну політику підтримки інновацій в реальному секторі економіки, знайти механізми впливу на ринок, які стимулюватимуть бізнес фрінансувати і впроваджувати нові технології (виробничі, управлінські) [1].

У Законі України «Про державно-приватне партнерство» ДПП визначене як - співробітництво між державою Україна, Автономною Республікою Крим, територіальними громадами в особі відповідних державних органів та органів місцевого самоврядування (державними партнерами) та юридичними особами, крім державних та комунальних підприємств, або фрізичними особами - підприємцями (приватними партнерами), що здійснюється на основі договору в порядку, встановленому Законом та іншими законодавчими актами, та відповідає ознакам державно-приватного партнерства, визначеним Законом [4].

У різних країнах набули поширення різні сорери застосування державно-приватного партнерства:

- Великобританія зосередила проекти ДПП на таких об'єктах інфраструктури, як школи, лікарні, тюрми, оборонні об'єкти і автомобільні дороги;

- Канада значну кількість проектів ДПП виконує в таких сорерах, як енергетика, транспорт, захист 
довкілля, водопостачання та водовідведення, рекреаційні об'єкти, інорормаційні технології, охорона здоров'я, освіта;

- Греція переважно виконує проекти ДПП у транспортній галузі;

- Ірландія визначила такі об'єкти ДПП, як автомобільні дороги та міські транспортні системи;

- Австралія пріоритетними напрямами для ДПП визначила транспорт і системи життєзабезпечення міст;

- Нідерланди застосовують механізм ДПП у громадському житловому секторі та системах життєзабезпечення міст;

- Іспанія реалізує проекти ДПП в будівництві та експлуатації платних автомобільних доріг та систем життєзабезпечення міст;

- США переважно виконують проекти ДПП, які об'єднують природоо-хоронну діяльність, життєзабезпечення сільських населених пунктів.

Успішний досвід реалізації проектів ДПП в Україні фрактично відсутній, хоча на державному рівні $€$ зацікавлення до таких проектів у сорері будівництва автошляхів та енергетиці [5].

Державно-приватне партнерство в інноваційно-інвестиційній сфері розглядається як нові технології розвитку економіки і є вагомим фрактором інноваційно-інвестиційної безпеки національної економіки. Сутність партнерства полягає в активній співпраці всіх суб'єктів, яка активізується на засадах пошуку спільних напрямів реалізації визначених цілей. Причому партнерами стають учасники всіх секторів інноваційного розвитку, зокрема: державного (управління і регулювання інноваційного розвитку економіки); продукування нових знань і інновацій; освіти і підвищення кваліфікації працівників; комерціалізації наукових знань і інновацій і використання інновацій [1].

Модель взаємодії держави і бізнесу в інноваційному процесі зводиться до розподілу ролей: роль приватного сектору полягає у розробленні технологій на основі власних досліджень, а також у ринковому освоєнні інновацій, роль держави у сприянні виникненню фундаментальних знань і комплексу технологій стратегічного характеру, а також у створенні інфрраструктури і сприятливих інституційних умов для інноваційної діяльності приватних компаній [2].

Можна виділити основні принципи, на яких засновані сучасні фрорми дПП в галузі розвитку інноваційної сорери [6]:

1) бюджетне фрінансування повинно виступати каталізатором інноваційних процесів;

2) співорінансування проектів з боку держави за збереження управління проектами в руках бізнесу або спеціалізованими посередницькими організаціями;

3) реалізація фрункцій підтримки держави інноваційних компаній через бізнес-посередників;
4) використання різних підходів держави до активізації інноваційної діяльності - як за рахунок адміністративної мотивації наявних інноваційних підприємств, так і шляхом створення інноваційних бізнес-одиниць;

5) розвиток інноваційних кластерів, у межах яких можливий ефректив-ний обмін кращим досвідом між малим і середнім бізнесом, зокрема за участю державних структур;

6) розвиток системи неформальних взаємодій між новаторами;

7) удосконалення нормативно-правової бази.

Основною перевагою ДПП порівняно з іншими видами договірних відносин між органами влади та приватним сектором є оптимальний розподіл повноважень щодо контролю над спільною діяльністю 3 надання послуг населенню, в результаті якої буде досягнуто бажаний результат для обох сторін. Це здійснюється шляхом договірного узгодження ролей, ризиків і винагород та отримання стимулів для якісного надання послуг водночас із використанням гнучких підходів для досягнення бажаних результатів [7, с. 16]. Порівняльну характеристику форм ДПП наведено в табл. 1.

Під час реалізації ДПП використовують різноманітні механізми співпраці державних структур та підприємств приватного сектору. Найбільш поширеними є такі (рис. 1).

Розглянемо організаційно-економічний механізм регулювання ДПП (рис. 2). Співпраця між державою та приватним сектором сприятиме як розвитку інвестиційної діяльності в країні, так і покращенню її економічного стану шляхом реалізації суспільно важливих інноваційних проектів. Як основне джерело фрінансування проектів ДПП розглядаємо інвестиційний ресурс банківського сектора. Особливу увагу необхідно приділити створенню програми гарантування банківських кредитів у розвиток економіки. Це стимулюватиме участь кредитних організацій у фрінансуванні пріоритетних галузей, зменшуючи витрати бюджету країни. Під час реалізації договорів кредитування реального сектора економіки банки надають послуги фрінансового менеджменту для позичальників. Банки беруть участь у складанні бізнес-планів інноваційного проекту, що в свою чергу приведе до підвищення якості укладеної угоди, зниження кредитних ризиків, удосконалення управління [13]. У межах реалізації механізму ДПП банківські установи отримують можливість посилити свою ресурсну базу та знизити кредитні ризики.

Цілями розвитку організаційно-економічного механізму мають стати: фрормування ефективних джерел ресурсів інноваційних проектів, створення умов для успішної реалізації стратегічних планів інноваційного розвитку національної економіки, фрормування механізмів забезпечення стабіль- 
Порівняльна характеристика форм державно-приватного партнерства

\begin{tabular}{|c|c|c|c|}
\hline $\begin{array}{c}\text { Форма } \\
\text { дПп }\end{array}$ & Різновиди форм ДПП & $\begin{array}{l}\text { Сутність та особливості } \\
\text { форми ДПП }\end{array}$ & $\begin{array}{c}\text { Права, витрати та ризики } \\
\text { учасників дПП }\end{array}$ \\
\hline Контракти & $\begin{array}{l}\text { Державні замовлення та } \\
\text { дозволи на виконання робіт, } \\
\text { контракти на виконання робіт, } \\
\text { надання суспільних послуг, } \\
\text { управління, постачання } \\
\text { продукції для державних } \\
\text { потреб, надання технічної } \\
\text { допомоги }\end{array}$ & \begin{tabular}{|l|} 
Адміністративний договір, \\
який укладається між \\
державою (органом місцевого \\
самоврядування) \\
і приватною фрірмою на \\
здійснення певних суспільно \\
необхідних \\
і корисних видів діяльності. \\
Приватний партнер за договором \\
отримує право на обумовлену \\
частку прибутку або зібраних \\
платежів, що, окрім престижу, \\
гарантують йому стійкий ринок \\
і дохід, а також можливі пільги і \\
преференції
\end{tabular} & $\begin{array}{l}\text { Права власності не } \\
\text { передаються приватному } \\
\text { партнеру, витрати і ризики } \\
\text { повністю несе держава }\end{array}$ \\
\hline Оренда & $\begin{array}{l}\text { Оренда в її традиційній фрормі } \\
\text { (договору оренди) і у формі } \\
\text { лізингу }\end{array}$ & $\begin{array}{l}\text { На визначених договором } \\
\text { умовах відбувається } \\
\text { передавання приватному } \\
\text { партнеру державного або } \\
\text { муніципального майна в } \\
\text { тимчасове користування і за } \\
\text { визначену плату }\end{array}$ & $\begin{array}{l}\text { Традиційні угоди оренди } \\
\text { передбачають повернення } \\
\text { предмету орендних відносин, } \\
\text { причому право } \\
\text { розпорядження майном } \\
\text { зберігається за власником і } \\
\text { не передається приватному } \\
\text { партнеру }\end{array}$ \\
\hline Концесія & $\begin{array}{l}\text { На об'єкти інфрраструктури, } \\
\text { які вже } \\
\text { існують; на будівництво } \\
\text { та модернізацію } \\
\text { інфраструктурних об'єктів; } \\
\text { передача права } \\
\text { управління об'єктами } \\
\text { державної власності } \\
\text { приватній, що } \\
\text { керує, компанії. У } \\
\text { межах цих видів } \\
\text { можливі варіанти } \\
\text { концесійних відносин }\end{array}$ & $\begin{array}{l}\text { Передавача державою } \\
\text { приватному концесіонеру права } \\
\text { довгострокового користування } \\
\text { державною } \\
\text { власністю для здійснення } \\
\text { прибуткової діяльності у сфері, } \\
\text { що має стратегічне значення, за } \\
\text { умови приватного інвестування } \\
\text { національних інноваційних } \\
\text { проектів розвитку передаються } \\
\text { об'єкти, що є виключно } \\
\text { державною монополією у } \\
\text { володіння й управління }\end{array}$ & $\begin{array}{l}\text { Держава в межах партнерських } \\
\text { відносин залишається } \\
\text { власником майна, яке є } \\
\text { предметом концесійної } \\
\text { угоди, уповноважує приватного } \\
\text { партнера виконувати } \\
\text { протягом визначеного терміну } \\
\text { обумовлені в угоді функції } \\
\text { і з цією метою наділяє його } \\
\text { відповідним правом. За } \\
\text { користування вносить плату. } \\
\text { Право власності на вироблену } \\
\text { за концесією продукцію } \\
\text { передається концесіонеру }\end{array}$ \\
\hline $\begin{array}{l}\text { Спільні } \\
\text { підприємства }\end{array}$ & $\begin{array}{l}\text { Акціонерні товариства, спільні } \\
\text { підприємства з пайовою } \\
\text { участю сторін. } \\
\text { Акціонерами в товариствах } \\
\text { можуть } \\
\text { виступати органи } \\
\text { держави та приватні інвестори }\end{array}$ & \begin{tabular}{|l|} 
Особливістю спільних \\
підприємств є постійна участь \\
держави в поточній виробничій, \\
адміністративно-господарський \\
та інвестиційній діяльності. \\
Можливості приватного партнера \\
щодо прийняття самостійних \\
адміністративно-господарських \\
рішень визначаються, як \\
правило, часткою в \\
акціонерному капіталі
\end{tabular} & $\begin{array}{l}\text { Права власності, витрати } \\
\text { та ризики розподіляються } \\
\text { пропорційно, відповідно } \\
\text { до пайових часток сторін } \\
\text { або кількості акцій }\end{array}$ \\
\hline $\begin{array}{l}\text { Угода про } \\
\text { розподіл } \\
\text { продукції }\end{array}$ & $\begin{array}{l}\text { За видами мінеральної } \\
\text { сировини або } \\
\text { ділянки надр }\end{array}$ & $\begin{array}{l}\text { Форма ДПП, що є договором, } \\
\text { відповідно до якого суб'єктові } \\
\text { підприємницької діяльності на } \\
\text { оплатній основі і у певний термін } \\
\text { надаються виняткові права на } \\
\text { пошук, розвідку і видобування } \\
\text { мінеральної сировини на ділянці } \\
\text { надр, вказаній в угоді, і ведення } \\
\text { пов'язаних із цим робіт. На } \\
\text { відміну від концесії, продукції } \\
\text { ПП належить не увесь обсяг } \\
\text { виробленої продукції, а лише } \\
\text { частка }\end{array}$ & $\begin{array}{l}\text { Держава надає своє виключне } \\
\text { право на використання } \\
\text { природних надр } \\
\text { приватному інвестору на } \\
\text { оплатній основі і у визначений } \\
\text { термін. Здійснити } \\
\text { проведення зазначених } \\
\text { робіт за свій рахунок і на } \\
\text { свій ризик. Розподіл продукції } \\
\text { може відбуватись } \\
\text { за різними схемами }\end{array}$ \\
\hline
\end{tabular}

Джерело: складено авторами на основі [8; 9; 10; 11] 


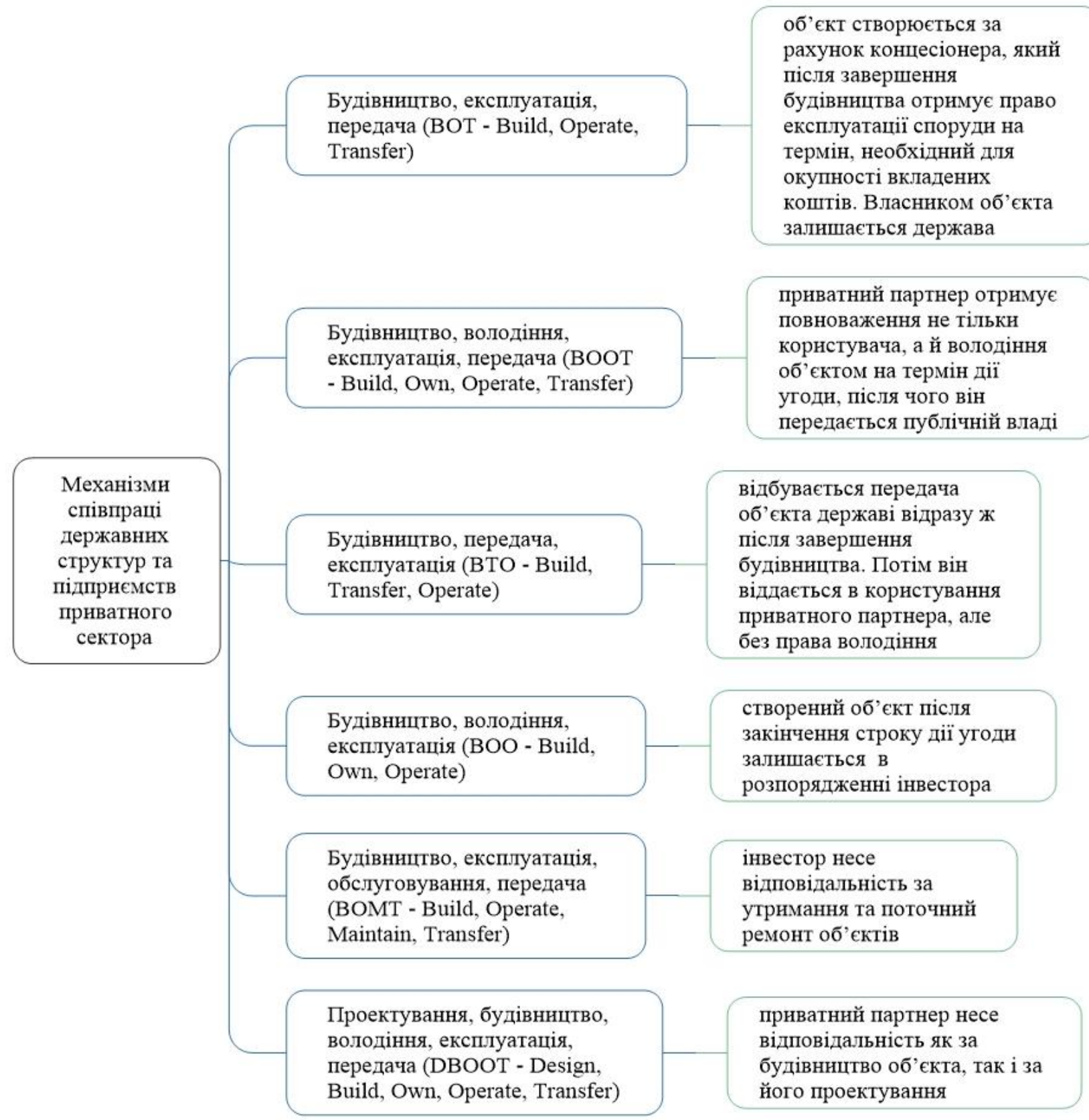

Рис. 1. Механізми співпраці державних структур та підприємств приватного сектору

Джерело: складено автором на основі [12; 8, с. 33-35]

ності та підвищення конкурентоспроможності економіки Україні.

Найважливішим елементом організаційно-економічного механізму $є$ науково-методична база реалізації інноваційних проектів на основі ДПП.

Висновки 3 проведеного дослідження. Впровадження дієвого організаційно-економічного механізму активізації інноваційної діяльності за рахунок державно-приватного партнерства відіграє важливу роль у контексті своєчасності реалізації інноваційних проектів, фрормування конкурентних переваг та посилення ефективності фрунціонування національної економіки у стратегічній перспективі.

Перспективним напрямом державно-приватного партнерства, а водночас - і стимулом інноваційного розвитку національної економіки, є передача частини функцій приватним структурам, які зараз належать державі. Наприклад, здійснення певної державної підтримки, зокрема у сорері інноваційного бізнесу, шляхом надання поручництва під час отримання кредитів, виконання завдань сертифікації, ліцензування, перевірки і засвідчення відповідності. 


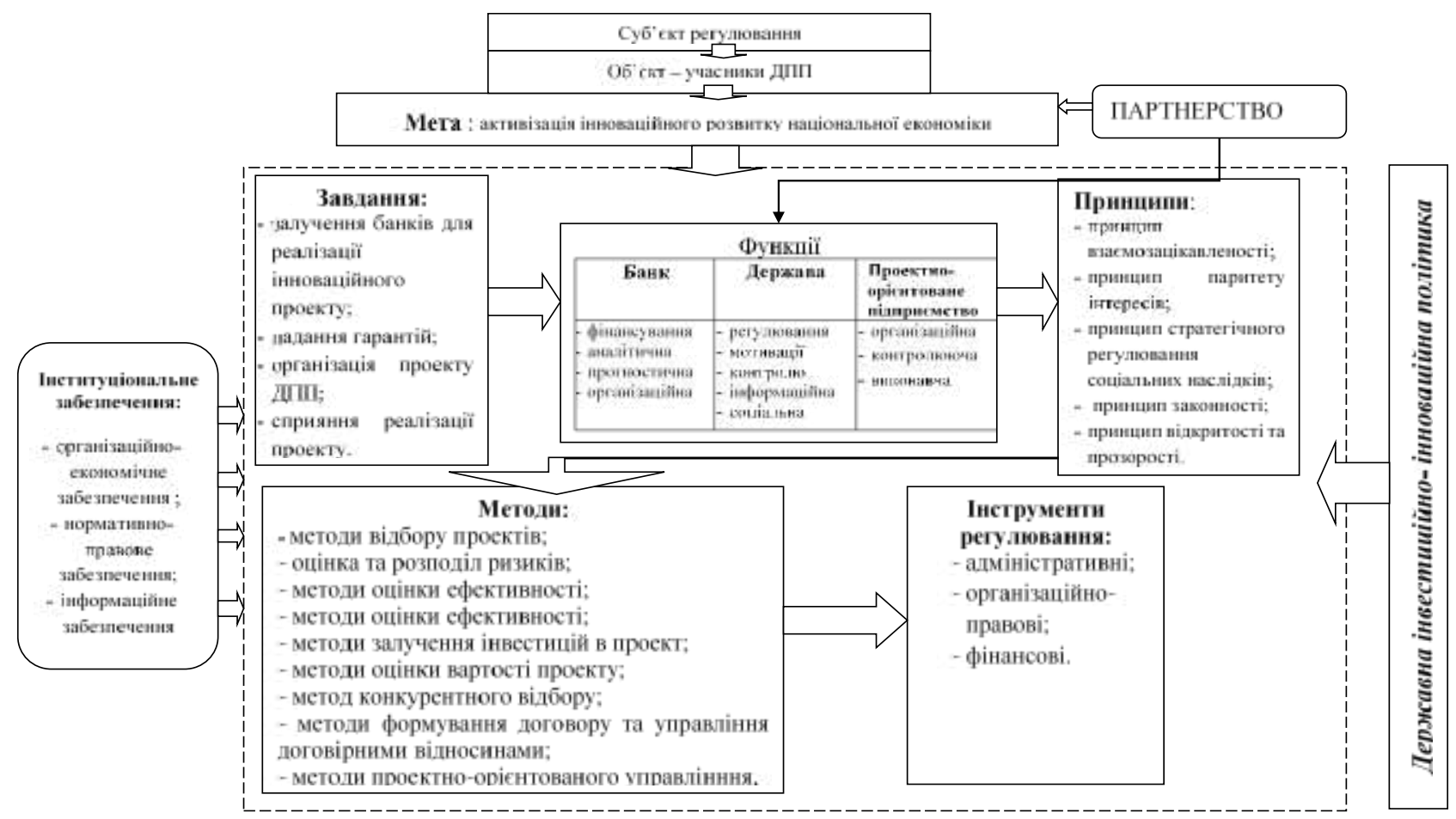

Рис. 2. Структура організаційно-економічного механізму регулювання ДпП

Джерело: розроблено автором

\section{БІБЛІОГРАФІЧНИЙ СПИСОК:}

1. Воронкова Т.Є., Воронков І.В. Державно-приватне партнерство як інструмент активізації інноваційної діяльності. Науково-технічна інсрормація. 2014. № 2, c. 28-36.

2. Нейкова I.C. Державно-приватне партнерство як складова інвести-ційного механізму інноваційного розвитку. Науковий вісник Національного університету ДПС України (економіка, право). 2010. № 1(48), c. 152-160.

3. Про схвалення Концепції реформування державної політики в інно-ваційній сфері: Розпорядження КМУ від 10 вересня 2012 р. № 691-p. URL: https://zakon.rada.gov.ua/laws/show/691-2012\%D1\%80 (дата звернення: 11.07.2019).

4. Закон України «Про державно-приватне партнерство» від 1 липня 2010 року № 2404-VI URL: https://zakon.rada.gov.ua/laws/show/2404-17 (дата звернення: 11.07.2019).

5. Карий О.І., Процак К.В., Мавріна А.О. Проекти державно-приватного партнерства: ключові проблеми практичної реалізації. Економічний аналіз : зб. наук. праць / Тернопільський національний економічний університет; редкол. : В. А. Дерій (голов. ред.) та ін. Тернопіль : Видавничо-поліграфічний центр Тернопільського національного економічного університету «Економічна думка». 2015. Т. 20,с. 35-44.

6. Инновационная политика : учебное пособие. / Гончаренко Л. П., Ю. А. АрутюнОв. М.: КНОРУС, 2009. $348 \mathrm{c}$.

7. Досвід та перспективи впровадження державно-приватних партнерств в Україні та за кордоном / [Винницький Б., Лендьел М., Онищук Б., Сегварі П. К.] : «К.І.С.», 2008. 146 с.
8. Варнавский В.Г. Государство и бизнес: институциональные аспекты. Мир перемен. 2004. № 2. C. 13.

9. Данілов О.Д. Інвестування: навч. посіб. / Данілов О.Д., Івашина Г.М., Чумаченко О.Г. Ірпінь: 2001. 377 c. URL : http://books.br.com.ua/23154 (дата звернення: 11.07.2019).

10. Єгорова О. Державно-приватне партнерство в портовому сегменті економіки України. Радикальний крок чи необхідність? Юрбізнес 2008. № 20 (155). URL: http://www.yur-gazeta.com/article/1570/ (дата звернення: 11.07.2019).

11. Шарингер Л. Новая модель инвестиционного партнерства государства и частого сектора. Мир Перемен. 2004. № 2. С. 3

12. GET Немецкая экономическая группа в Беларуси. Минск, 2007. URL : http://www.ipm.by/pdf/10r.pdf (дата звернення: 11.07.2019).

13. Філіпова Н.В. Регулювання державно-приватного партнерства в Україні Науковий вісник Чернігівського державного інституту економіки і управління : 3б. наук. праць Чернігів : ЧДІЕУ, 2014. № 4. С. 26-33. Серія : Економіка)

\section{REFERENCES:}

1. Voronkova T.Ye., Voronkov I.V. (2014) Derzhavnopryvatne partnerstvo iak instrument aktyvizatsii innovatsijnoi diial'nosti [Public-private partnership as a tool for enhancing innovation]. Naukovo-tekhnichna informatsiia, vol. 2, pp. 28-36. (in Ukrainian).

2. Nejkova I.S. (2010) Derzhavno-pryvatne partnerstvo iak skladova investytsijnoho mekhanizmu innovatsijnoho rozvytku [Public-private partnership as 
a component of the investment mechanism of innovative development]. Naukovyj visnyk Natsional'noho universytetu DPS Ukrainy (ekonomika, pravo), vol. 1, pp. 152-160. (in Ukrainian).

3. Pro skhvalennia Kontseptsii reformuvannia derzhavnoi polityky $v$ inno-vatsijnij sferi: Rozporiadzhennia KMU vid 10 veresnia 2012 r. № 691-r. Available at : https://zakon.rada.gov.ua/laws/show/691-2012-\% D1\%80 (accessed 11 July 2019).

4. The Verkhovna Rada of Ukraine (2010) Zakon Ukrainy «Pro derzhavno-pryvatne partnerstvo» vid 1 lypnia 2010 roku № 2404-VI [The Law of Ukraine "On public-private partnership"], available at: https://zakon.rada.gov.ua/laws/show/2404-17 (accessed 11 July 2019).

5. Karyj O.I., Protsak K.V., Mavrina A.O. (2015) Proekty derzhavno-pryvatnoho partnerstva: kliuchovi problemy praktychnoi realizatsii [Public-private partnership projects: key problems of practical implementation]. Ekonomichnyj analiz : zb. nauk. prats' / Ternopil's'kyj natsional'nyj ekonomichnyj universytet; redkol. V. A. Derij (holov. red.) ta in. Ternopil' : Vydavnycho-polihrafichnyj tsentr Ternopil's'koho natsional'noho ekonomichnoho universytetu "Ekonomichna dumka", vol. 20, pp. 35-44. (in Ukrainian).

6. Goncharenko L.P., Ju.A. Arutjunov. (2009) Innovacionnaja politika : uchebnoe posobie [Innovative policy: a tutorial]. Moscow: KNORUS, p. 348. (in Russian).

7. Vynnyts'kyj B., Lend'el M., Onyschuk B., Sehvari P. (2008) Dosvid ta perspektyvy vprovadzhennia derzhavno-pryvatnykh partnerstv v Ukraini ta za kordonom
[Experience and prospects for the implementation of public-private partnerships in Ukraine and abroad]. Kyiv: «K.I.S.», p. 146. (in Ukrainian).

8. Varnavskij V. G. (2004) Gosudarstvo i biznes: institucional'nye aspekty [State and business: institutional aspects]. Mir peremen, vol. 2, p. 13. (in Russian).

9. Danilov O.D., Ivashyna H.M., Chumachenko O.H. (2001) Investuvannia [Elektronnyj resurs] : navch. posib. [Investment]. Irpin, p. 377. Available at : http://books.br.com.ua/23154 (accessed 11 July 2019).

10. Yehorova O. (2008) Derzhavno-pryvatne partnerstvo $\mathrm{v}$ portovomu seh-menti ekonomiky Ukrainy. Radykal'nyj krok chy neobkhidnist'? [Elektronnyj resurs]. [Public-private partnership in the port segment of the economy of Ukraine. A radical step or need?]. Yurbiznes, vol. 20. Available at : http://www.yur-gazeta.com/ article/1570/ (accessed 11 July 2019).

11. Sharinger L. (2004) Novaja model' investicionnogo partnerstva gosudarstva i chastogo sektora [New model of investment partnership of the state and private sector]. Mir peremen, vol. 2, p. 3. (in Russian).

12. (2007) GET Nemeckaja jekonomicheskaja gruppa $\vee$ Belarusi [GET Ger-man Economic Group in Belarus]. Minsk. Rezhim dostupu do fajlu : http://www.ipm.by/pdf/10r.pdf (accessed 11 July 2019).

13. Filipova N.V. (2014) Rehuliuvannia derzhavnopryvatnoho partnerstva v Ukraini [Public-private partnership as a tool for enhancing innovation]. Naukovyj visnyk Chernihivs'koho derzhavnoho instytutu ekonomiky i upravlinnia : zb. nauk. prats' (Seriia : Ekonomika), vol. 4, pp. 26-33. (in Ukrainian). 
Filipova Nataliia

Candidate of Economic Sciences, Associate Professor, Senior Lecturer at Department of Public Administration and Management of Organizations Chernihiv National University of Technology

Starchenko Grygoriy

Candidate of Technical Sciences, Associate Professor, Doctoral Student of Department of Public Administration and Management of Organizations

Chernihiv National University of Technology

\section{PUBLIC-PRIVATE PARTNERSHIPS AS FINANCIAL MECHANISM OF PROVIDING INNOVATIVE DEVELOPMENT OF THE NATIONAL ECONOMY}

The purpose of the article. The social and economic development of the country depends on conducting a consistent innovation policy and the effective implementation of the innovation model at all levels of government. The purpose of the study is to study the organizational and economic mechanism of activating innovation activity at the expense of public-private partnership.

Emphasizing on the necessity of organizational and economic mechanism developing for activating innovation activity at the expense of public-private part-nership, the following tasks need to be addressed: to analyze the experience of us-ing PPP as an innovation development, to investigate forms of PPP, to consider the organizational and economic mechanism of PPP regulation.

Methodology. A wide range of methods is used to study the objective set out in this article: analysis and synthesis, induction and deduction, historical (for clarification of the essence of public-private partnership and refinement of catego-ries); formalization, analogy, system analysis (to determine the functions of public-private partnership, factors of development of public-private partnership); statistical, analytic grouping.

Results. The article deals with the organizational and economic mechanism of activation of innovation activity at the expense of public-private partner-ship. The main attention is paid to maximizing business participation in innovative processes in Ukraine. There were analyzed areas of application of public-private partnership in different countries (USA, Spain, Australia, Nederland, Ireland, Greece, Canada, Great Britain). It was revealed that public-private partnership in the innovation-investment sphere is considered as new technologies of economic development and is a significant factor of innovation and investment security of the national economy. The main principles of public-private partners in innovation are highlighted (1) budget financing should act as a catalyst for innovation processes; 2 ) co-financing state projects while maintaining project management in the hands of business or specialized intermediary organizations; 3 ) implementation of the functions of support of the state of innovative companies through business intermediaries; 4) the use of different approaches of the state to the activation of innovative activities - both at the expense of administrative motivation of existing innovative enterprises, and through the creation of innovative business units; 5) the development of innovative clusters, within which an efficient exchange of best practices between small and medium-sized businesses is possible, in particular with the participation of state structures; 6 ) development of a system of informal interactions between innovators; 7) improvement of the regulatory framework. It is noted that the main advantage of PPP is the optimal allocation of powers to control the joint activities of providing services to the population.

It was mentioned that the main advantage of PPP is the optimal allocation of powers to control the joint activities of providing services to the population. Also, in the article there is a comparative description of PPP forms, mechanisms of cooperation between state structures and private sector. The analysis allowed to consider the structure of the organizational and economic mechanism of regulation of PPP objectives, which is to develop effective sources of innovation resources, creating conditions for successful implementation of strategic plans of innovation in the development of national economy, stability and competitiveness of the economy of Ukraine.

The most important element of the organizational and economic mechanism is the scientific and methodological basis for the implementation of innovative projects on the basis of PPP.

Practical implications. The introduction of an effective organizational and economic mechanism for activating innovation activity at the expense of public-private partnership plays an important role in the context of the timeliness of the implementation of innovative projects, the formation of competitive advantages and enhancement of the efficiency of the functioning of the national economy in the strategic perspective.

Value/originality. The introduction of an effective organizational and eco-nomic mechanism for activating innovation activity at the expense of public-private partnership plays an important role in the context of the timeliness of the implementation of innovative projects, the formation of competitive advantages and enhancement of the efficiency of the functioning of the national economy in the strategic perspective. 